\title{
GESTUR DALAM PEMBELAJARAN MATEMATIKA MATERI IRISAN KERUCUT DAN KOORDINAT POLAR
}

\author{
Yunis Sulistyorini \\ Program Studi Pendidikan Matematika, IKIP Budi Utomo Malang \\ *Email korespondensi: yunis.sulistyorni@gmail.com
}

\begin{abstract}
ABSTRAK
Gestur berperan dalam pembelajaran matematika khususnya pada materi Irisan Kerucut dan Koordinat Polar. Gestur pendidik berhubungan dengan perencanaan konseptual dari penjelasan yang akan disampaikan dan merupakan perwujudan pengetahuan dan pemahaman dari pendidik terkait dengan materi yang dipelajari. Gestur yang dihasilkan pendidik merupakan gestur menunjuk, representasi dan menulis. Gestur muncul pada tahap perencanaan, terutama kegiatan peer teaching, dan pelaksanaan pembelajaran. Kedua tahap tersebut berkaitan dengan penerapan lesson study pada pembelajaran matematika. Gestur yang mengiringi penjelasan pendidik membantu mengklarifikasi, menjelaskan, dan menekankan konsep matematis pada materi yang dipelajari.
\end{abstract}

Kata kunci: gestur, lesson study, irisan kerucut, koordinat polar

\begin{abstract}
Gestures played a role in the learning of mathematics, especially in the Sliced Cone and Polar Coordinates material. Educators gestures associated with conceptual planning of the explanations and is the embodiment of knowledge and understanding of educators associated with the material being studied. The educators' gestures were pointing gestures, representations and writing. Gestures appeared at the planning stage, especially the activities of peer teaching and learning implementation. Both of two steps related to the implementation of lesson study in math learning. Gestures accompanied explanations educators help to clarify, explain, and emphasize mathematical concepts in the material being studied.
\end{abstract}

Keywords: gesture, lesson study, sliced cone, polar coordinates

\section{PENDAHULUAN}

Gestur merupakan salah satu alat komunikasi lintas budaya dan bahasa. Penjelasan pendidik yang diiringi gestur memungkinkan komunikasi yang efektif antara pendidik dan siswa termasuk dalam pembelajaran matematika. Penjelasan yang dikombinasikan dengan gestur merupakan alat komunikasi yang memungkinkan pembicaraan yang lebih bermakna (Castellon \& Enyedi, 2006). Gestur juga membantu siswa dalam mempelajari konsep atau 
materi yang abstrak. Alibali \& Nathan (2007) menyatakan bahwa gestur berperan sebagai salah satu bentuk scaffold dari pendidik agar konsep atau infomasi yang disampaikan dapat dipahami dengan lebih baik oleh siswa karena gestur merupakan salah satu mekanisme yang dapat menghubungkan hal yang abstrak dengan hal yang konkret.

Peneliti yang bertindak sebagai dosen model mempertimbangkan peranan gestur dalam pada pembelajaran matematika dengan menerapkan lesson study. Sedangkan peranan gestur dalam penelitian dibatasi pada tahap perencanaan dan pelaksanaan pembelajaran di kelas untuk materi Irisan Kerucut dan Koordinat Polar dengan sub materi Luas dalam Koordinat Polar. Menurut Rock and Wilson (2005), lesson study diperlukan untuk mengembangkan profesional guru dan pembelajaran di kelas. Dalam lesson study dilakukan pengembangan instrumen dan perangkat pembelajaran, metode dan model pembelajaran, bahan ajar dan evaluasi yang memungkinkan terwujudnya profesionalisme pendidik secara utuh (Marsigit, 2007).

Ibrohim (2009) dalam Subanji (2014) menyatakan bahwa kegiatan dalam lesson study terdiri dari tiga tahap yaitu: (1) plan (perencanaan), (2) do (pelaksanaan), dan (3) see (refleksi). Pada tahap plan dilakukan perencanaan pembelajaran dan penyiapan alat-alat dengan mempertimbangan beberapa hal antara lain pemahaman apa yang dimiliki peserta didik tentang suatu topik, pemahaman apa yang diharapkan dari peserta didik setelah akhir pembelajaran, aktivitas apa yang dilakukan oleh peserta didik dalam pembelajaran, kesalahan apa yang mungkin muncul dalam pembelajaran, bagaimana menggunakan ide dan kesalahan untuk meningkatkan pembelajaran, bagaimana rancangan pembelajaran yang mampu memotivasi peserta didik dan apa bukti belajar peserta didik. Selanjutnya pada tahap do pendidik melaksanakan pembelajaran dengan menerapkan perencanaan pembelajaran di kelas. Dalam tahap ini teman sejawat atau pendidik lain dalam satu tim dan pakar menjadi observer. Pada tahap akhir yaitu see pendidik pelaksana pembelajaran diberikan kesempatan pertama untuk melakukan refleksi kemudian dilanjutkan dengan tanggapan dari para observer, diskusi tentang hasil pengolahan data dari observer dan tanggapan serta saran dari pakar.

\section{METODE PENELITIAN}

Penelitian menggunakan pendekatan kualitatif untuk mendeskripsikan peranan gestur dalam pembelajaran materi irisan kerucut. Pembelajaran tersebut terkait dengan penerapan lesson study. Data dalam penelitian diperoleh melalui tahap perencanaan dan pelaksanaan 
dalam pembelajaran materi Irisan Kerucut dan Koordinat Polar. Materi hanya dibatasi pada subbab Luas dalam Koordinat Polar. Gestur pendidik dalam penelitian ini didefinisikan sebagai gestur yang dihasilkan oleh peneliti yang bertindak sebagai dosen model atau pendidik dalam pembelajaran sub materi Luas dalam Koordinat Polar. Pengumpulan data dilakukan melalui dokumentasi video pada tahap perencanaan dan pelaksanaan pembelajaran di kelas. Data yang sudah dikumpulkan kemudian dianalisis dan dideskripsikan berdasarkan pengklasifikasian gestur menjadi gestur menunjuk, gestur representasi dan gestur menulis.

\section{HASIL DAN PEMBAHASAN}

Gestur pendidik berperan dalam pembelajaran matematika. Gestur pendidik adalah tindakan atau gerakan tangan pendidik yang berhubungan dengan tugas matematis (Shein, 2012). Tindakan atau gerakan pendidik yang tidak berkontribusi langsung pada tugas matematis, misalnya ekspresi wajah, tidak diperhatikan sebagai gestur pendidik. Penjelasan yang dikombinasikan dengan gestur merupakan alat komunikasi yang memungkinkan pembicaraan yang lebih bermakna (Castellon \& Enyedi, 2006). Sebagai salah satu alat komunikasi, gestur efektif dalam mengasesmen pengetahuan siswa. Gestur tidak hanya berhubungan dengan pembicaraan yang disampaikan tetapi juga berhubungan dengan perencanaan konseptual dari pembicaraan yang akan disampaikan tersebut (Alibali, dkk, 2000).

Gestur sering digunakan sebagai bukti bahwa tubuh dilibatkan dalam pemikiran dan penyampaian ide yang diwujudkan dalam gestur tersebut dan bukti perwujudan pengetahuan matematis merupakan bagian yang tak terpisahkan dari komunikasi ide matematis (Alibali \& Nathan, 2012). Hal yang sama juga ditunjukkan bahwa gestur berhubungan dengan pengetahuan atau pemahaman seseorang (Edward, 2009) dan pemikiran matematis seseorang (Alibali, dkk, 2000). Menurut Cook dan Goldin-Meadow (2006), gestur pendidik dapat memfasilitasi pembelajaran dengan membantu siswa memahami kalimat yang menyertai gestur tersebut. Castellon dan Enyedy (2006) menyatakan bahwa penjelasan pendidik yang diiringi dengan gestur akan jauh lebih baik daripada penjelasan tanpa gestur. Secara rinci, Castellon dan Enyedy (2006) menyatakan bahwa gestur yang mengiringi penjelasan dapat membantu mengklarifikasi, menjelaskan, memperjelas dan menekankan konsep matematis pada siswa. Gestur pendidik juga berperan dalam menerjemahkan bahasa instruksional ke dalam kehidupan nyata seperti benda, diagram, tindakan atau referensi fisik lainnya (Alibali \& 
Nathan, 2007). Dalam hal ini, Alibali \& Nathan (2007) menyatakan gestur berperan sebagai salah satu bentuk scaffold dari pendidik agar konsep atau infomasi yang disampaikan dapat dipahami dengan lebih baik oleh siswa karena gestur merupakan salah satu mekanisme yang dapat menghubungkan hal yang abstrak dengan hal yang konkret.

Gestur seharusnya lebih sering digunakan pendidik ketika mengenalkan materi baru yang belum dikenalkan sebelumnya, mengajarkan materi yang lebih kompleks dan menanggapi pertanyaan dan komentar dari siswa (Alibali \& Nathan, 2007). Tiga jenis gestur pendidik yang perlu diperhatikan dalam pembelajaran matematika adalah pointing gesture atau gestur menunjuk, representational gesture atau gestur representasi dan writing gesture atau gestur menulis.

\section{Gestur Menunjuk}

Gestur menunjuk merupakan gestur yang paling banyak digunakan pendidik. Gestur menunjuk merupakan penggunaan jari, tangan atau terkadang alat tulis untuk menspesifikasikan obyek fisik, tempat, orang atau untuk menunjukkan bagian yang tidak dijelaskan secara visual dalam penjelasan (Shein, 2012). Gestur menunjuk ini berperan dalam memfokuskan perhatian siswa, menempatkan obyek pada suatu waktu dan tempat, menghubungkan obyek secara fisik, menspesifikasikan obyek penting dalam pendeskripsian dan memastikan bahwa siswa dapat mengikuti langkah-langkah pendidik dalam mencapai tujuan pembelajaran (Shein, 2012).

Pendidik seringkali menggunakan gestur ini dalam pembelajaran matematika. Ketika pendidik menunjuk suatu objek sambil memberikan penjelasan, informasi yang disampaikan menjadi terhubung dengan objek yang ditunjuk. Gestur ini dapat membantu siswa mengurangi beban kerja memori dalam mengkodekan dan memproses informasi atau pengetahuan yang dipelajari (Alibali \& Nathan, 2012; Goldin-Meadow, dkk, 2001; Ping \& Goldin-Meadow, 2010). Penggunaan gestur menunjuk dapat dilihat ketika pendidik menunjukkan variabel, koefisien dan konstanta dalam operasi aljabar atau ketika menjelaskan perbedaan diagonal sisi dan bidang dalam balok.

\section{Gestur Representasi}

Gestur representasi adalah tindakan atau gerakan yang menggambarkan ide, obyek atau kejadian baik yang konkret maupun abstrak dalam penjelasan (Shein, 2012). Gestur ini secara 
visual memberikan hubungan formal yang erat antara konten semantik dan penjelasan dengan menggambarkan objek atau kejadian yang konkret atau abstrak. Contoh penggunaan gestur ini adalah ketika pendidik mensimulasikan gerakan pada perubahan kemiringan suatu garis. Pendidik juga dapat menggunakan gestur ini untuk menerjemahkan konsep sudut siku-siku dalam objek yang nyata. Dalam hal ini pendidik membentuk kedua telapak tangannya sedemikian sehingga menggambarkan suatu sudut siku-siku.

\section{Gestur Menulis}

Gestur menulis adalah penulisan atau penggambaran yang mengiringi penjelasan secara lisan (Shein, 2012). Tulisan yang dihasilkan berhubungan dengan penjelasan sama seperti gerakan tangan berhubungan dengan penjelasan. Gestur ini berperan dalam menekankan bagian dari penjelasan dan memberikan catatan-catatan untuk menjelaskan materi yang disampaikan pendidik. Gestur ini akan meninggalkan tanda misalnya pada papan tulis atau lembar kerja siswa.

Gestur merupakan bagian yang tidak dapat dipisahkan dari pembelajaran matematika. Pendidik bisa jadi menghasilkan lebih dari satu gestur dalam suatu waktu, misalnya menghasilkan gestur menunjuk dan menulis untuk menekankan letak sudut-sudut yang bersesuaian pada dua segitiga yang sebangun. Menurut Alibali dan Nathan (2007), secara umun urutan gestur yang paling banyak digunakan selama pembelajaran adalah gestur menunjuk, gestur representasi dan gestur menulis.

Gestur pendidik muncul ketika pembelajaran sub materi Luas dalam Koordinat Polar. Gestur muncul pada tahap perencanaan dan pelaksanakan pembelajaran. Pada tahap perencanaan dilakukan persiapan pelaksanaan pembelajaran dengan melakukan kegiatan peer teaching. Aktivitas dalam kegiatan ini divideokan sebagai dokumentasi kegiatan perencanaan dan memperbaiki praktek pembelajaran di kelas sebenarnya. Pada tahap pelaksanaan, pendidik menerapkan pembelajaran sesuai perencanaan yang sudah disusun sebelumnya. Pembelajaran Rotasi Sumbu dimulai dengan menjelaskan penurunan rumus untuk rotasi sumbu dengan mengingat kembali hubungan antara koordinat kartesius dan koordinat polar kemudian dilanjutkan dengan ilustrasi contoh dan latihan soal. Setelah itu, dilanjutkan dengan pembahasan mengenai penentuan sudut untuk melakukan rotasi sumbu yang dilanjutkan dengan latihan soal. Sedangkan dalam pembelajaran Luas dalam Koordinat Polar dimulai dengan mengingat kembali pendekatan Rieman dalam koordinat kartesius sebagai pengantar 
menjelaskan penurunan rumus luas dalam koordinat polar. Setelah itu, dibahas beberapa soal untuk mengilustrasikan penentuan batas-batas pengintegralan untuk menentukan luas daerah dalam koordinat polar. Terdapat dua ilustrasi tersebut untuk menentukan batas-batas pengintegralan yaitu ilustrasi untuk luas daerah dalam 1 grafik polar dan luas daerah di antara 2 grafik polar atau lebih. Setelah itu, mahasiswa diminta mengerjakan latihan soal untuk semakin memantapkan materi luas dalam koordinat polar.

Dalam kegiatan peer teaching dan pelaksanaan pembelajaran, gestur yang dihasilkan adalah gestur menunjuk, representasi dan menulis. Gestur pendidik berhubungan dengan perencanaan konseptual dari penjelasan yang akan disampaikan dan merupakan perwujudan pengetahuan dan pemahaman dari pendidik terkait dengan materi Luas dalam Koordinat Polar. Hal ini berhubungan dengan tahap perencanaan pembelajaran yaitu diskusi untuk pemantapan dan pemahaman materi serta kegiatan peer teaching. Gestur yang mengiringi penjelasan pendidik membantu mengklarifikasi, menjelaskan, memperjelas dan menekankan konsep matematis pada materi yang dipelajari. Hal ini sesuai dengan pernyataan dari Castelon \& Enyedi (2006) pada pembahasan sebelumnya. Penjelasan dengan gestur akan jauh lebih baik jika dibandingkan dengan penjelasan tanpa disertai gestur. Hal ini berhubungan dengan kegiatan peer teaching dan pelaksaaan pembelajaran di kelas. Ketiga jenis gestur muncul dalam pembelajaran yaitu gestur menunjuk, gestur representasi dan gestur menulis. Beberapa gestur yang muncul dalam kegiatan peer teaching dan pelaksanaan pembelajaran disajikan dalam tabel berikut ini. Tabel memuat jenis gestur yang muncul, gerakan yang dihasilkan dan peranan gestur tersebut dalam pembelajaran matematika untuk sub materi Luas dalam Koordinat Polar.

Gestur menunjuk yang muncul adalah gerakan menunjuk salah satu gambar irisan, menunjuk gambar irisan dan perhitungan luas secara bersamaan, dan menunjuk rumus perhitungan luas dalam koordinat polar. Gestur representasi yang muncul adalah gerakan mendekatkan jari telunjuk dan ibu jari untuk menggambarkan hubungan banyak dan ukuran irisan. Selain itu, gestur representasi yang muncul adalah gerakan menelusuri gambar seperempat lingkaran, setengah lingkaran dan satu lingkaran penuh. Gestur menulis muncul ketika pendidik menulis rumus, menggambar irisan grafik yang dicari luas daerahnya dengan persegi panjang atau juring lingkaran dan menggambar lingkaran dan juring. Gestur 
dipertimbangkan untuk menerapkan pembelajaran yang lebih efektif dalam pembelajaran matematika.

Tabel 1. Gestur yang Muncul dalam Pembelajaran

\begin{tabular}{|c|c|c|c|}
\hline Jenis Gestur & & Gestur yang Muncul & Peranan \\
\hline \multirow[t]{3}{*}{ Gestur menunjuk } & a. & $\begin{array}{l}\text { Menunjuk salah satu } \\
\text { irisan }\end{array}$ & $\begin{array}{l}\text { Mengarahkan perhatian siswa } \\
\text { pada irisan yang ditunjuk oleh } \\
\text { pendidik }\end{array}$ \\
\hline & b. & $\begin{array}{l}\text { Menunjuk irisan dan } \\
\text { perhitungan luas secara } \\
\text { bersamaan }\end{array}$ & $\begin{array}{l}\text { Menekankan hubungan } \\
\text { masing-masing irisan dan } \\
\text { perhitungan luasnya }\end{array}$ \\
\hline & c. & $\begin{array}{l}\text { Menunjuk rumus } \\
\text { perhitungan luas dalam } \\
\text { koordinat polar }\end{array}$ & $\begin{array}{l}\text { Menspesifikasikan rumus } \\
\text { yang digunakan untuk } \\
\text { menghitung luas yang dicari }\end{array}$ \\
\hline \multirow[t]{2}{*}{ Gestur representasi } & a. & $\begin{array}{l}\text { Mendekatkan jari } \\
\text { telunjuk dan ibu jari }\end{array}$ & $\begin{array}{l}\text { Menggambarkan bahwa } \\
\text { ketika banyak irisan semakin } \\
\text { mendekati takhingga maka } \\
\text { irisan akan semakin kecil }\end{array}$ \\
\hline & b. & $\begin{array}{l}\text { Menelusuri gambar } \\
\text { seperempat lingkaran, } \\
\text { setengah lingkaran dan } \\
\text { satu lingkaran penuh }\end{array}$ & $\begin{array}{l}\text { Menggambarkan perbedaan } \\
\text { batas-batas yang digunakan } \\
\text { ketika menghitung luas } \\
\text { lingkaran dengan menghitung } \\
4 \text { kali seperempat lingkaran, } \\
\text { dua kali setengah lingkaran } \\
\text { atau satu kali lingkaran penuh }\end{array}$ \\
\hline \multirow[t]{6}{*}{ Gestur menulis } & a. & Menulis rumus & Memberikan informasi \\
\hline & & & $\begin{array}{ll}\text { mengenai rumus } & \text { yang } \\
\text { dijelaskan secara lisan } & \end{array}$ \\
\hline & b. & $\begin{array}{l}\text { Menggambar irisan } \\
\text { grafik yang dicari luas }\end{array}$ & $\begin{array}{l}\text { Menekankan perbedaan antara } \\
\text { irisan untuk menghitung luas }\end{array}$ \\
\hline & & daerahnya dengan & daerah pada koordinat \\
\hline & & $\begin{array}{l}\text { persegi panjang atau } \\
\text { juring lingkaran }\end{array}$ & kartesius dan koordinat polar \\
\hline & c. & $\begin{array}{l}\text { Menggambar lingkaran } \\
\text { dan juring }\end{array}$ & $\begin{array}{l}\text { Membantu siswa menemukan } \\
\text { luas juring }\end{array}$ \\
\hline
\end{tabular}

\section{KESIMPULAN}

Gestur berperan dalam pembelajaran sub materi Luas dalam Koordinat Polar. Gestur pendidik berhubungan dengan perencanaan konseptual dari penjelasan yang akan disampaikan dan merupakan perwujudan pengetahuan dan pemahaman dari pendidik terkait dengan materi Luas dalam Koordinat Polar. Gestur yang mengiringi penjelasan pendidik membantu mengklarifikasi, menjelaskan, memperjelas dan menekankan konsep matematis pada materi 
yang dipelajari. Gestur yang dihasilkan pendidik merupakan gestur menunjuk, representasi dan menulis. Gestur muncul pada tahap perencanaan dan pelaksanaan pembelajaran. Untuk mengetahui reaksi siswa terhadap gestur yang dihasilkan pendidik dapat dilakukan penelitian dan analisis yang lebih mendalam pada tahap refleksi pembelajaran. Pembahasan gestur pendidik dalam tahap refleksi pembelajaran merupakan salah satu hal yang dapat dipertimbangkan untuk merencanakan pembelajaran yang lebih efektif.

\section{REKOMENDASI}

Untuk penelitian atau kajian berikutnya, gestur dapat diterapkan dalam pembelajaran matematika untuk materi selain Luas dalam Koordinat Polar. Pendidik dapat mempertimbangkan gestur untuk diterapkan dalam mempelajari konsep yang abstrak.

\section{REFERENSI}

Albali, M. W., Kita, Sotaro \& Young, A. J. (2000). Gesture and the Process of Speech Production: We think, therefore We Gesture. Language and Cognitive Processes, 15 (6): 593-613.

Alibali, M. W., \& Nathan, M. J. (2007). Teachers' gestures as a Means of Scaffolding Students' Understanding: Evidence from an Early Algebra Lesson. In R. Goldman, R. Pea, B. Barron, \& S. J. Derry (Eds.), Video research in the learning sciences (pp. 349366). Mahwah, NJ: Erlbaum.

Alibali, M. W., \& Nathan, M. J. (2012). Embodiment in Mathematics Teaching and Learning: Evidence From Learners' and Teachers' Gestures. Journal of the Learning Sciences, 21(2), 247-286.

Castellon, V. C \& Enyedy, N. (2006). Teacher's Speech and Gesture as a Communicative and Strategic Tool to Convey and Discuss Mathematical Concepts in a Bilingual Algebra Classroom. AERA, San Fransisco.

Cook, S. W. \& Goldin-Meadow, S. (2006). The Role of Gesture in Learning: Do Children Use Their Hands to Change Their Minds? Journal of Cognition and Development, 7 (2), 211 232.

Edwards, L. (2009). Gesture and Conceptual Integration in Mathematical Talk. Jornal Internacional de Estudos em Educação Matemática, 1(1), 33-46. 
Goldin-Meadow, S., Nusbaum, H., Kelly, S. D., Cook, S. W. (2001). Explaining Math: Gesturing Lightens the Load. Psychological Science, 12(6), 516-522.

Marsigit. (2007). Mathematics Teachers' Profesional Development through Lesson study in Indonesia. Eurasia Journal of Mathematics, Science \& Technology Education, 3(2): 141144.

Ping, R. \& Goldin-Meadow, S. (2010). Gesturing Saves Cognitive Resources when Talking about Nonpresent Objects. Cognition Science, 34: 602-619.

Rock, Tracy C \& Wilson, Cathy. (2005). Improving Teaching through Lesson Study. Teacher Education Quarterly.

Shein, P. P. (2012). Seeing with Two Eyes: A Teachers Use of Gesture in Questioning and Revoicing to Engage English Language Learners in the Repair of Mathematical Errors. Journal for Research in Mathematics Education, 43 (2), 182-222.

Subanji. (2014). Panduan Praktik Pengalaman Lapangan (PPL) Berbasis Project Lesson Study Prodi S2 Pendidikan Matematika. Pendidikan Matematika Pascasarjana Universitas Negeri Malang. 